\title{
Differential Physiological Responses and Genetic Variations in Fine Fescue Species for Heat and Drought Stress
}

\author{
Jinyu Wang ${ }^{1}$, Patrick Burgess ${ }^{1}$, Stacy A. Bonos, William A. Meyer, and Bingru Huang ${ }^{2}$ \\ Department of Plant Biology and Pathology, Rutgers University, New Brunswick, NJ 08901
}

\begin{abstract}
AdDitional INDEX wORDs. turf quality, chlorophyll content, electrolyte leakage, photochemical efficiency
Aвstract. Summer decline is typically characterized by heat and drought stress and is a major concern for fine fescue species (Festuca). The objectives of this study were to examine whether heat or drought stress is more detrimental, and to determine the genotypic variations in heat and drought tolerance for fine fescues. A total of 26 cultivars, including seven hard fescues (Festuca trachyphylla), eight chewings fescues (Festuca rubra ssp. commutate), seven strong creeping red fescues (Festuca rubra ssp. rubra), two sheep fescues (Festuca ovina ssp. hirtula), and two slender creeping red fescues (Festuca rubra ssp. littoralis) were subjected to prolonged heat or drought stress in growth chambers. Several physiological parameters, including turf quality (TQ), electrolyte leakage (EL), photochemical efficiency $\left(F_{\mathrm{v}} / F_{\mathrm{m}}\right)$ chlorophyll content $(\mathrm{Chl})$, and relative water content $(\mathrm{RWC})$ were measured in plants exposed to heat or drought stress. The results indicated that heat stress was more detrimental than drought stress for fine fescue species. Based on TQ and major physiological parameters (EL and $\left.F_{\mathrm{v}} / F_{\mathrm{m}}\right)$ under heat stress, several cultivars with good heat tolerance were selected, including 'Blue Ray', 'Spartan II', 'MN-HD1', 'Shoreline', 'Navigator II', 'Azure', 'Beacon', ‘Aurora Gold', 'Reliant IV', 'Marco Polo', 'Garnet', 'Wendy Jean', 'Razor', and 'Cindy Lou'. Based on TQ and major physiological parameters (EL, RWC, and $\left.F_{\mathrm{v}} / F_{\mathrm{m}}\right)$ under drought stress, several cultivars with good drought tolerance were selected, including 'Spartan II', 'MN-HD1', 'Reliant IV', 'Garnet', 'Azure', and 'Aurora Gold'. These cultivars could be used in hot, dry, or both environments and as breeding germplasm for developing heat tolerance, drought tolerance, or both.
\end{abstract}

The optimal growing temperature for cool-season grass species ranges from 18 to $23{ }^{\circ} \mathrm{C}$, whereas air temperatures typically exceed 30 to $35^{\circ} \mathrm{C}$ for daytime and 23 to $28{ }^{\circ} \mathrm{C}$ for nighttime during summer months in the transition zone (Kunkel et al., 2013). Drought stress is another major limiting factor for turfgrass growth, particularly during the summer months. The decline in TQ of fine fescues, which is commonly observed during the summer, is typically associated with heat, drought, or both and is referred as summer decline (Turgeon, 1996). Evaluating the stress-induced TQ decline caused by heat or drought and comparing responses across cultivars would offer a better understanding of the summer decline in fine fescues.

Healthy turfgrass stands are characterized by uniform and dense canopy, dark-green leaf color, and active growth (Beard, 1972). Extensive reports have shown that stressrelated leaf senescence is associated with disruption or degradation of cellular membranes with downstream effects on photosynthetic carbohydrate synthesis (Huang et al., 2014; Wahid et al., 2007). Prolonged heat stress typically induces lipid peroxidation and membrane instability with subsequent effects on chlorophyll integrity and net photosynthetic rates in cool-season grass species, including creeping bentgrass (Agrostis stolonifera), kentucky bluegrass

Received for publication 31 Mar. 2017. Accepted for publication 29 June 2017. The authors wish to acknowledge the funding support by the National Institute of Food and Agriculture, U.S. Department of Agriculture, Specialty Crops Research Initiative under award number 2012-51181-19932. The authors also thank Stephanie Rossi and Cathryn Chapman for critically reviewing the manuscript.

${ }^{1}$ Authors with equal contribution.

${ }^{2}$ Corresponding author. E-mail: huang@aesop.rutgers.edu.
(Poa pratensis), and perennial ryegrass (Lolium perenne) (Jiang and Huang, 2001; Liu and Huang, 2000). Alternatively, drought stress caused by decreased rainfall or limited irrigation is another major problem leading to steady TQ decline of cool-season turfgrass stands during the summer months. Although drought stress similarly imposes negative effects on cellular membrane stability, photochemical efficiency, and chlorophyll integrity, it also induces significant decreases in leaf water potential in kentucky bluegrass (Abraham et al., 2004; Jiang and Huang, 2000). Similar effects of drought stress have been detected in other coolseason grasses including tall fescue (Festuca arundinacea), creeping bentgrass, and perennial ryegrass (Carrow and Duncan, 2003; Karcher et al., 2008; McCann and Huang, 2008; Wang and Bughrara, 2008). Given that drought and heat stress typically occur together under field conditions, it is important to determine which stress is more detrimental so that proper management can be taken to prevent or control summer decline in fine fescues.

The fine fescue family is comprised of several species and subspecies, including strong creeping red fescue, slender creeping red fescue, chewings fescue, hard fescue, and sheep fescue. Fine fescue species are cool-season grasses widely used in home lawns and golf courses throughout cooltemperate climates. They form attractive turf stands that are characterized by narrow and fine leaf textures (Christians and Engelke, 1994). They are well adapted to poor soil fertility, moderate shade, and acidic soil conditions; however, little is known regarding their tolerance to heat and drought stress (Turgeon, 2011). The objectives of this study were to 1) examine whether heat or drought stress (dry down by withholding irrigation) is more detrimental to fine fescues, 


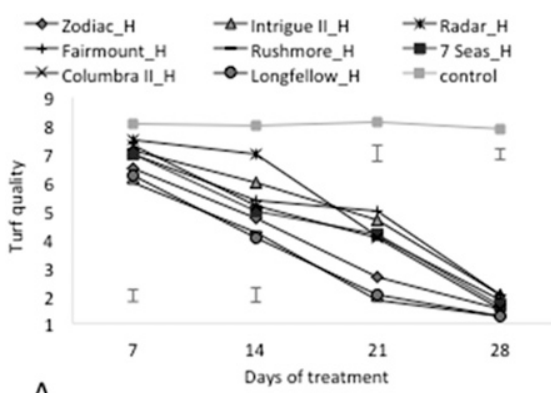

A

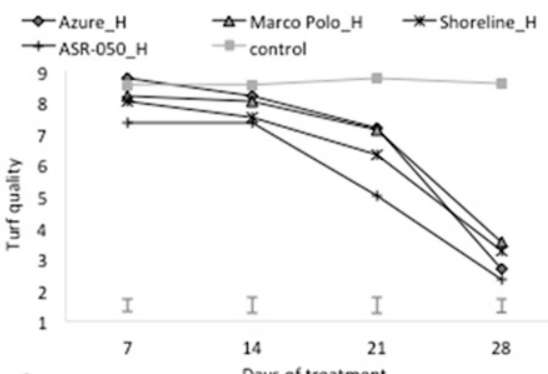

C

Days of treatment
B

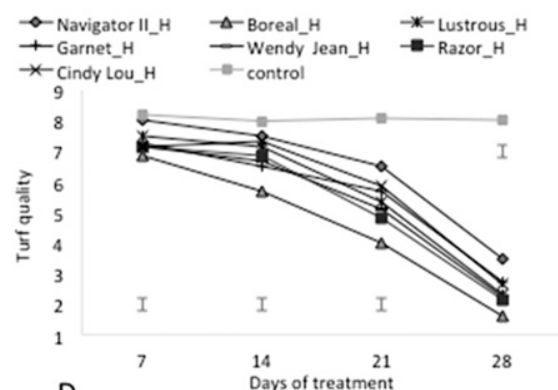

D

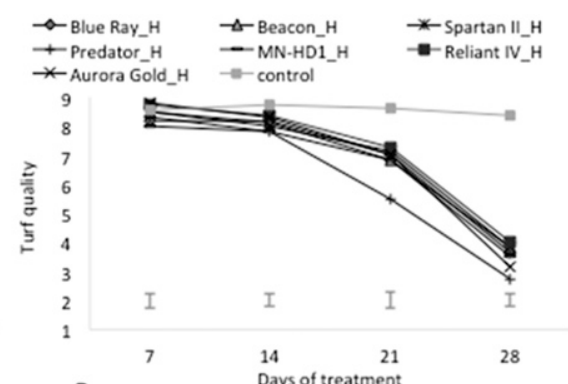

\section{Materials and Methods}

Plant materials and growth Conditions. A total of 26 cultivars of fine fescue were evaluated in the study: seven hard fescues ('Blue Ray', 'Beacon', 'Spartan II', 'Predator', 'MN-HD1', 'Reliant IV', and 'Aurora Gold'), eight chewings fescues ('Zodiac', 'Intrigue II', 'Radar', 'Fairmount', 'Rushmore', '7 Seas', 'Columbia II', and 'Longfellow'), seven strong creeping red fescues ('Navigator II', 'Boreal', 'Lustrous', 'Garnet', 'Wendy Jean', 'Razor', and 'Cindy Lou'), two sheep fescues ('Azure' and 'Marco Polo'), and two slender creeping red fescues ('Shoreline' and 'ASR-050'). Seeds for each cultivar were sterilized in $1 \%$ $(\mathrm{v} / \mathrm{v})$ sodium hypochlorite solution for $1 \mathrm{~min}$, rinsed with sterile water, and sown at $19.5 \mathrm{~g} \cdot \mathrm{m}^{-2}$ seed. The seeds for heat stress and its corresponding control were sown in sterile sand (autoclaved at $\left.121{ }^{\circ} \mathrm{C}, 124.1 \mathrm{kPa}, 60 \mathrm{~min}\right)$ in plastic pots $(15 \mathrm{~cm}$ diameter $\times$ $14 \mathrm{~cm}$ depth) on 2 Apr. 2014. The seeds for drought stress and its corresponding control were sown in sterile fritted clay medium (Profile Products, Deerfield, IL) in plastic pots $(10 \mathrm{~cm}$ diameter $\times 40 \mathrm{~cm}$ depth) on 2 Apr. 2014. Plants were maintained in greenhouse for $48 \mathrm{~d}$ and treated with $0.032 \mathrm{mg} \cdot \mathrm{m}^{-2}$ azoxystrobin (Heritage; Syngenta Crop Protection, Greensboro, NC) and $0.055 \mathrm{mg} \cdot \mathrm{m}^{-2}$ cyazofamid (Segway; FMC Corp., Philadelphia, PA) every $21 \mathrm{~d}$ to prevent pathogen infection. Greenhouse environmental conditions were $23 / 20{ }^{\circ} \mathrm{C}$ (day/night), $700 \mathrm{mmol} \cdot \mathrm{m}^{-2} \cdot \mathrm{s}^{-1}$ photosynthetically active radiation $(P A R)$ from sunlight and supplemental lighting, $60 \%$ relative humidity (RH), and 14-h photoperiod. Plants were irrigated daily to maintain well-irrigated conditions, trimmed twice per week to maintain a 7-cm canopy height, and applied with half-strength Hoagland's nutrient solution every $4 \mathrm{~d}$ during establishment. After the establishment period, the

2) determine genotypic variations of heat and drought tolerance within fine fescues, and 3) identify physiological parameters that can be used as indicators for heat and drought tolerance in fine fescues. plants were transferred to controlled-environment growth chambers (Environmental Growth Chambers, Chagrin Falls, OH) at $21 / 18^{\circ} \mathrm{C}$ (day/night), $650 \mathrm{mmol} \cdot \mathrm{m}^{-2} \cdot \mathrm{s}^{-1} P A R$, $60 \% \mathrm{RH}$, and 14-h photoperiod for $7 \mathrm{~d}$ to allow plants to 


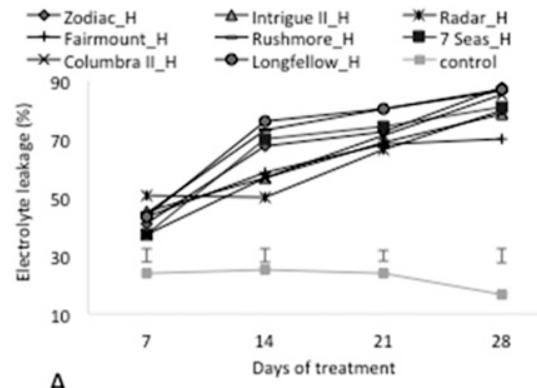

A
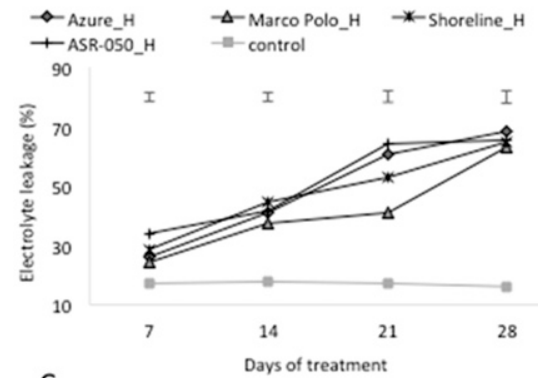

C

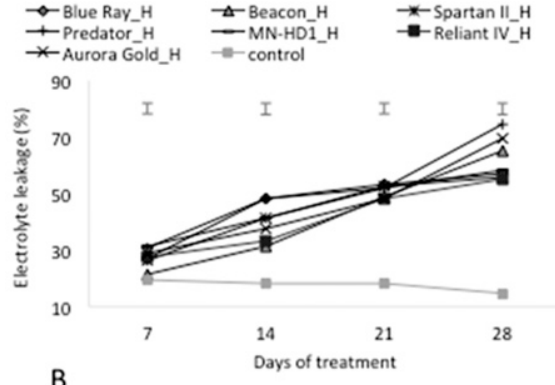

B
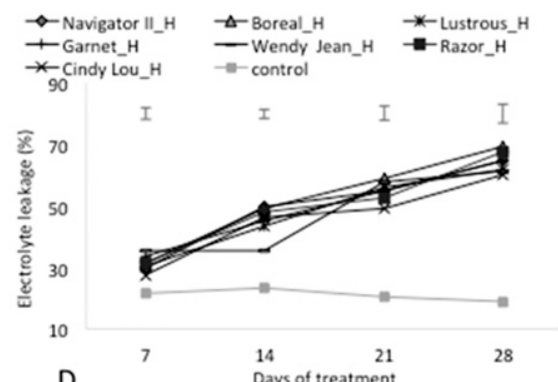

D
2014. Two distinct sets of nonstress control plants respective to heat or drought stress treatments were used. For drought treatment, irrigation was withheld for $28 \mathrm{~d}$, and volumetric soil water content (SWC) began to decrease to below the control level at $4 \mathrm{~d}$ of water withholding, and decreased to $7.0 \%$ by $28 \mathrm{~d}$ of drought treatment, whereas SWC of nonstress control containers was maintained at the pot capacity $(\approx 29 \%)$ by daily irrigation. During drought treatment, all environmental conditions were the same as those previously described during the chamber acclimation period. For heat treatment, plants were subjected to heat stress for $28 \mathrm{~d}$ by increasing the growth chamber day/ night temperatures to $38 / 33{ }^{\circ} \mathrm{C}$, whereas nonstress controls containers were maintained at $21 / 18{ }^{\circ} \mathrm{C}$ (day/night). All other environmental conditions were the same as those previously described during the chamber acclimation period.

The experiment was arranged in a split-plot treatment arrangement, with stress treatment (heat, drought, or nonstress control) as the main plot and plant cultivar (within each species) as the subplot. Each main plot (drought, heat, or nonstress control) was replicated in four different growth chambers with one growth chamber as one replicated main plot. Each cultivar (subplot) was replicated in four containers, which were placed across four different growth chambers of heat, drought, or nonstress treatment (main plots), with one container per chamber. All cultivars (subplots) were arranged randomly within each growth chamber. Plants were relocated or rerandomized within each of the four growth chambers every $3 \mathrm{~d}$ to minimize possible edge effects of the environmental conditions within a chamber.

SoIl WATER CONTENT AND Physiological analysis. The SWC was monitored using a time reflectometer (Trase System1; Soilmoisacclimate to growth chamber conditions before stress imposition.

Treatments AND EXPERIMENTAL DESIGN. After establishment and acclimation to growth chamber conditions, 416 containers (26 cultivars $\times 4$ treatments $\times 4$ replications) were subjected to heat, drought, or two nonstress control treatments on 26 May ture Equipment Corp., Santa Barbara, CA). Three waveguide probes, each measuring $30 \mathrm{~cm}$ in length, were inserted into the root zone, and SWC was measured for drought and nonstress treatments every day (Topp et al., 1980).

The RWC was measured to determine leaf hydration status at $4,14,21$, and $28 \mathrm{~d}$ of drought treatment. About $0.2 \mathrm{~g}$ leaf 


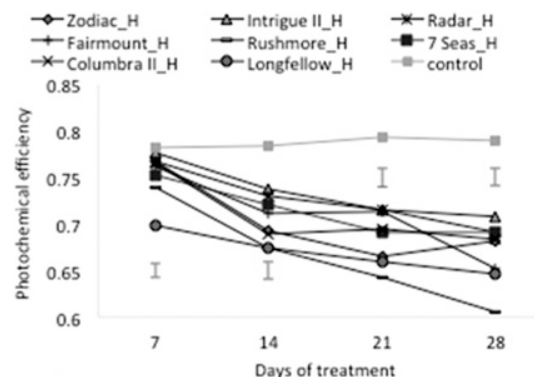

A

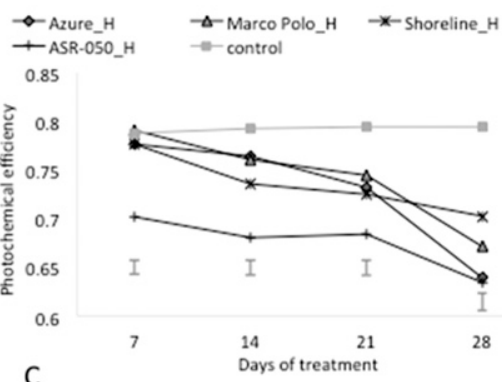

C

Fig. 5. Photochemical efficiency of (A) chewings fescue, (B) hard fescue, (C) sheep fescue and slender creeping red fescue, and (D) strong creeping red fescue as affected by heat stress compared with control. Control line shows the averaged value of all cultivars. The letter " $\mathrm{H}$ " after each cultivar name stands for heat stress treatment. Vertical bars of the figure indicate least significant difference values $(P \leq 0.05)$ for comparison at a given day of treatment.

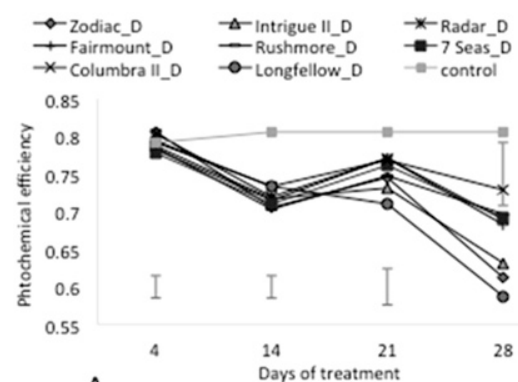

A

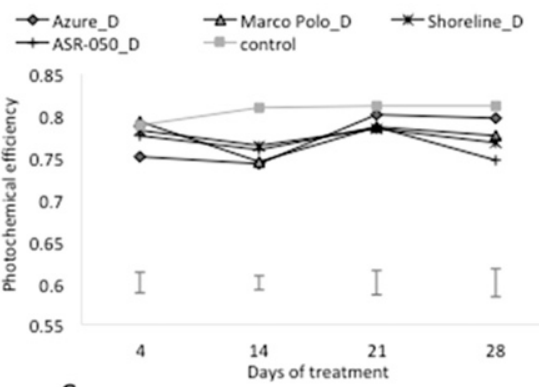

C

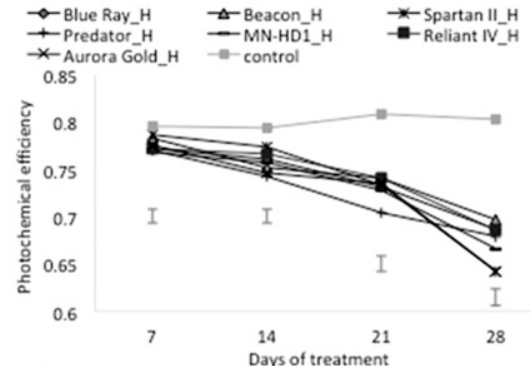

B

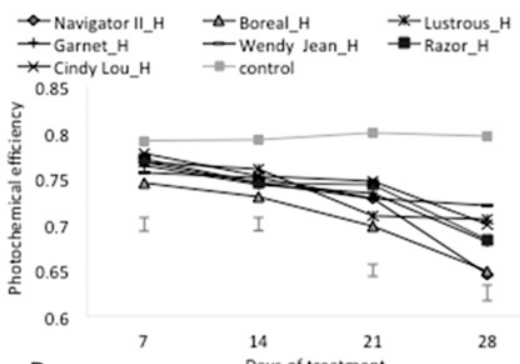

D
Bard fescue, $($ C) sheep fescue and slender creeping
H" after each compltivar name stands for heat stress
icant difference values $(P \leq 0.05)$ for comparison at

RWC was calculated using the formula $[(\mathrm{FW}-\mathrm{DW}) /(\mathrm{TW}-$ DW) $] \times 100$ (Barrs and Weatherley, 1962).

Leaf membrane stability was estimated by measuring EL at 4, 14, 21 , and $28 \mathrm{~d}$ of drought treatment and at $7,14,21$, and $28 \mathrm{~d}$ of heat treatment. About $0.2 \mathrm{~g}$ leaf tissue was collected, rinsed with deionized water, and placed in a test tube containing $30 \mathrm{~mL}$ deionized water. The tubes were agitated on a shaker for $12 \mathrm{~h}$ and the initial conductance $\left(C_{\mathrm{i}}\right)$ of the incubation solution was measured using a conductivity meter (YSI, Yellow Springs, OH). Leaf tissue was then killed by autoclaving at $121{ }^{\circ} \mathrm{C}$ for $20 \mathrm{~min}$, agitated for $12 \mathrm{~h}$, and the maximal conductance $\left(C_{\max }\right)$ of incubation solution was measured. Leaf EL was calculated using the formula $\left(C_{\mathrm{i}} / C_{\max }\right) \times 100$ (Blum and Ebercon, 1981).

The Chl was determined according to the methods described by Hiscox and Israestem (Hiscox and Israelstam, 1979) with modifications. The measurement was taken at $4,14,21$, and $28 \mathrm{~d}$ of drought treatment and at $7,14,21$, and $28 \mathrm{~d}$ of heat treatment. Leaf tissue $(0.1 \mathrm{~g})$ was collected and incubated in $10 \mathrm{~mL}$ dimethyl sulfoxide in darkness for $72 \mathrm{~h}$ to extract chlorophyll from tissue. The resulting solution was analyzed on a spectrophotometer (Spectronic Instruments, Rochester, NY) at 663 and $645 \mathrm{~nm}$. The remaining tissue was filtered and dried in an oven at $80{ }^{\circ} \mathrm{C}$ for $72 \mathrm{~h}$ to obtain dry weights. Chlorophyll content was then calculated on a dry weight basis according to the equations described by Arnon (1949). The ratio of Chl was calculated using the formula [ $(\mathrm{Chl}$ at stress condition $) /(\mathrm{Chl}$ at control condition)].

The $F_{\mathrm{v}} / F_{\mathrm{m}}$ was measured as a ratio of the variable fluorescence $\left(F_{\mathrm{v}}\right)$ value to the maximum fluorescence $\left(F_{\mathrm{m}}\right)$ value using a chlorophyll fluorescence meter (Fim 1500; Dynamax, Houston, TX). Leaf clips were first used to dark-

tissue was collected and fresh weight (FW) was measured immediately after harvesting. Leaves were then submerged in deionized water for $12 \mathrm{~h}$ at $4{ }^{\circ} \mathrm{C}$, blotted dry, and again weighed for turgid weight (TW). Leaves were then dried in an oven at $80^{\circ} \mathrm{C}$ for $3 \mathrm{~d}$ and weighed to determine dry weight (DW). Leaf adapt the leaves for 30 mins and then the $F_{\mathrm{v}} / F_{\mathrm{m}}$ was determined with the fluorescence meter. The measurement was taken at 4,14, 21, and $28 \mathrm{~d}$ of drought treatment and at 7, 14, 21 , and $28 \mathrm{~d}$ of heat treatment. Two subsample measurements were taken per plant per sampling day. 


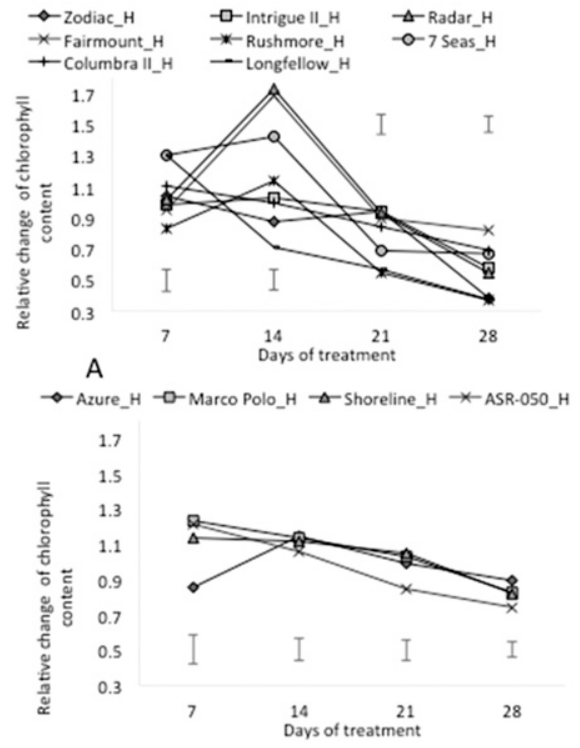

C
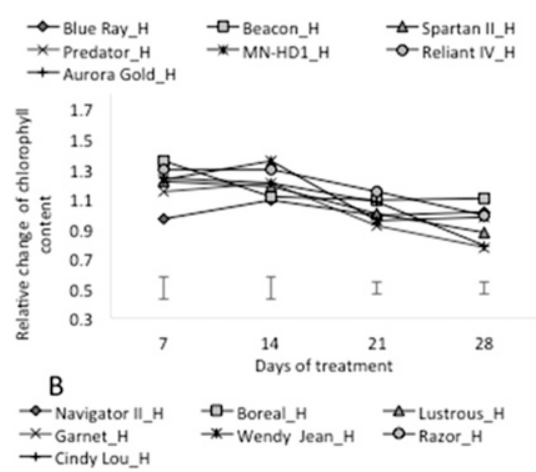

$\stackrel{-}{*}$-Garnet_H

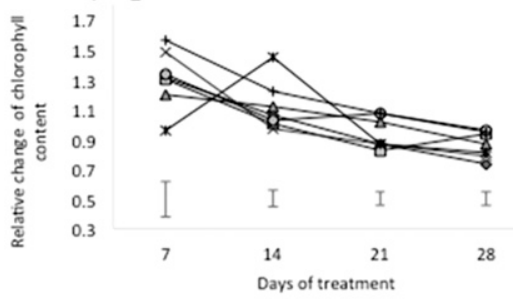

D

Fig. 7. Relative change in chlorophyll content under heat stress compared with control of (A) chewings fescue, (B) hard fescue, (C) sheep fescue and slender creeping red fescue, and (D) strong creeping red fescue. The letter " $\mathrm{H}$ " after each cultivar name stands for heat stress treatment. Vertical bars of the figure indicate least significant difference values $(P \leq 0.05)$ for comparison at a given day of treatment.

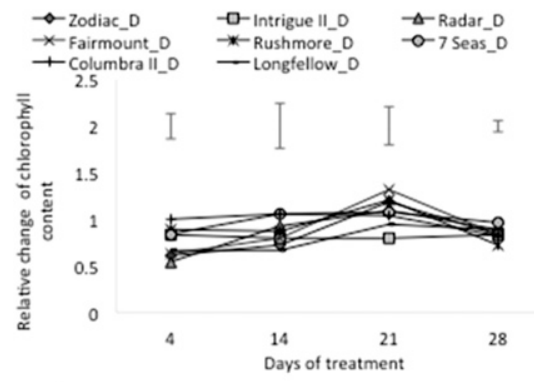

A

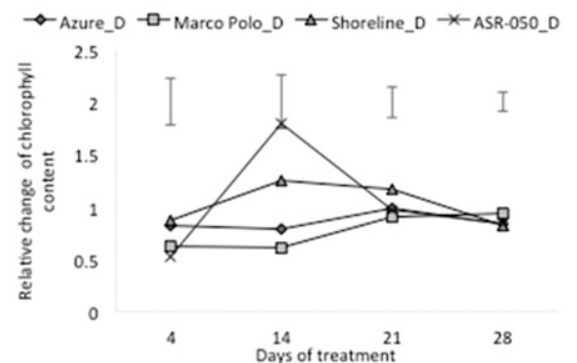

C

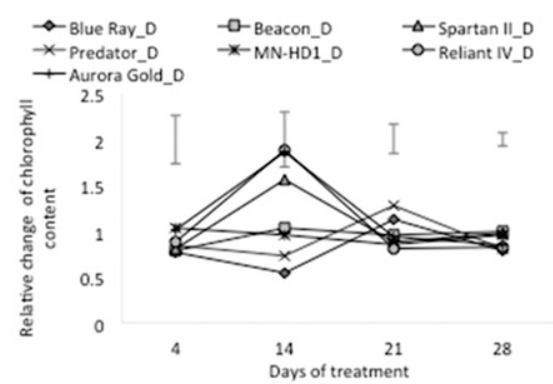

B

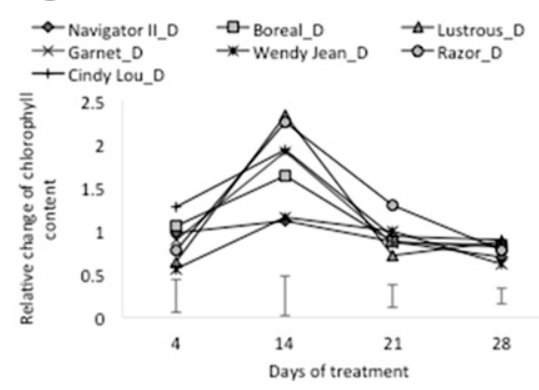

D

Fig. 8. Relative change in chlorophyll content under drought stress compared with control of (A) chewings fescue, (B) hard fescue, (C) sheep fescue and slender creeping red fescue, and (D) strong creeping red fescue. The letter "D" after each cultivar name stands for heat stress treatment. Vertical bars of the figure indicate least significant difference values $(P \leq 0.05)$ for comparison at a given day of treatment

Visual evaluation of TQ was performed to evaluate overall turfgrass performance on a scale of 1 to 9 , with 1 being brown and desiccated turf, 6 being the minimal acceptable level, and 9 being green and healthy turf. Ratings were based on canopy uniformity, visual attractiveness, leaf color, and canopy density.

Statistical analysis. General linear model analysis was performed within each fine fescue species using SAS (version
9.3; SAS Institute, Cary, NC) to determine differences between cultivars within a species in response to treatment. The cultivar differences were separated by the least significance difference test at the $0.05 P$ level. Correlation analysis, analysis of variance (ANOVA) and Ward's cluster analysis were performed across all fine fescue cultivars using the JMP statistical discovery software (SAS Institute). Ward's analysis provides an overall ranking of heat or drought tolerance on all evaluated fine fescue cultivars.

\section{Results}

Overall tURF PERFormance AND PHYSIOLOGICAL RESPONSES TO HEAT AND DROUGHT STRESS. A significant TQ decline was detected beginning from $7 \mathrm{~d}$ of heat stress in chewings fescues, slender creeping red fescues, and strong creeping red fescues, whereas not until $14 \mathrm{~d}$ for hard fescues and sheep fescues (Fig. 1). By the end of the heat treatment (28 d), TQ of the hard fescues were 2.8-4.0, sheep fescues, slender creeping red fescues, or strong fescues were $2.7-3.5,2.3-3.3$, or $2.7-$ 3.5 , respectively, whereas TQ of chewings fescues were 1.3-2.0. Under drought stress, a significant decline in TQ was detected beginning at $7 \mathrm{~d}$ of drought treatment in all fine fescue species (Fig. 2). By the end of 28-d drought treatment, TQ of chewings fescues were 3.7-4.2, hard and sheep fescues were 5.58.2 and 6.5-7.8, respectively, and slender creeping and strong creeping red fescues were 4.7-5.3 and $4.2-7.0$, respectively.

A significant increase in EL in response to heat stress was detected as early as $7 \mathrm{~d}$ of heat treatment in all fine fescue species and cultivars (Fig. 3). Chewings fescues showed a rapid EL increase during heat stress and reached $70 \%$ to $87 \%$ at the end of heat treatment $(28 \mathrm{~d})$, whereas hard fescues, sheep fescues, slender creeping red fescues, and strong creeping red fescues reached $55 \%$ to $75 \%, 63 \%$ to $69 \%, 65 \%$, and $60 \%$ to $69 \%$, respectively, at the end of heat treatment. A significant EL increase can be detected beginning from $21 \mathrm{~d}$ of drought treatment for chewings fescues and slender creeping red fescues and detected at $28 \mathrm{~d}$ for hard fescues, sheep fescues, and strong creeping red fescues (Fig. 4). Leaf EL of chewings fescues and strong creeping red fescues 


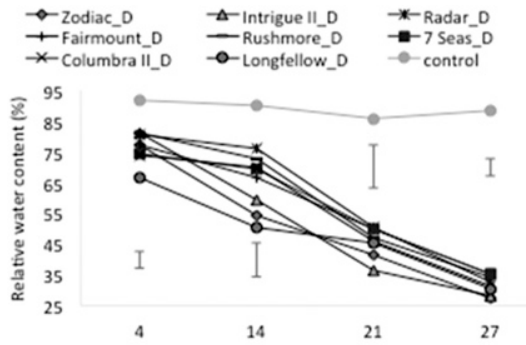

A

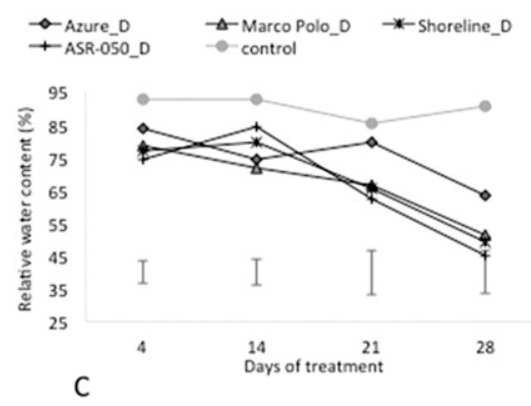

Fig. 9. Relative water content (\%) of (A) chewings fescue, $(\mathbf{B})$ hard fescue, $(\mathbf{C})$ sheep fescue and slender creeping red fescue, and (D) strong creeping red fescue as affected by drought stress compared with control. Control line shows the averaged value of all cultivars. The letter " $D$ " after each cultivar name stands for heat stress treatment. Vertical bars of the figure indicate least significant difference values $(P \leq 0.05)$ for comparison at a given day of treatment.

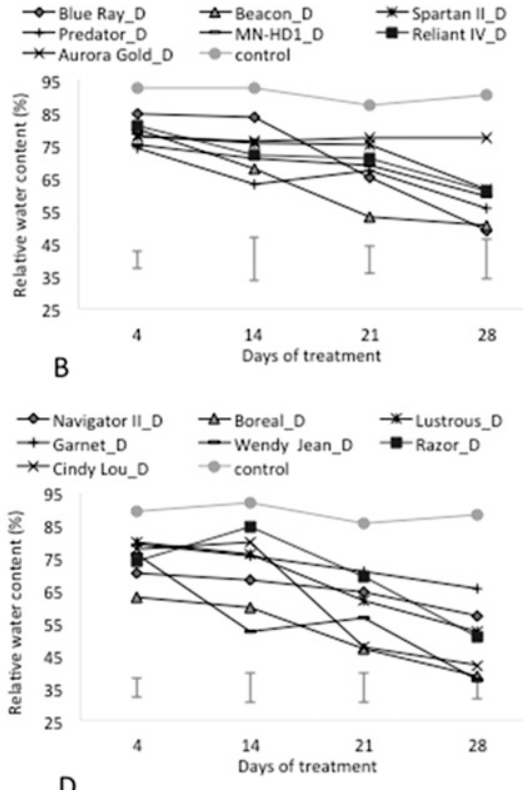

Table 1. Summary of the analysis of variance for the effects of treatment, duration of treatment, or genotype and their interactions on turf quality (TQ), electrolyte leakage (EL), chlorophyll content $(\mathrm{Chl})$, and photochemical efficiency $\left(F_{\mathrm{v}} / F_{\mathrm{m}}\right)$ measured at $7,14,21$, and $28 \mathrm{~d}$ of heat treatment for 26 cultivars of hard fescue, chewings fescue, strong creeping red fescue, sheep fescue, and slender creeping red fescue.

\begin{tabular}{lllllr}
\hline Source of variance & TQ & EL & Chl & $F_{\mathrm{v}} / F_{\mathrm{m}}$ & $\mathrm{df}$ \\
\hline Treatment (TRT) & $* *$ & $* *$ & NS & $* *$ & 1 \\
Duration of treatment (D) & $* *$ & $* *$ & $* *$ & $* *$ & 3 \\
Genotype (G) & $* *$ & $* *$ & $* *$ & $* *$ & 25 \\
TRT $\times$ D & $* *$ & $* *$ & $* *$ & $* *$ & 3 \\
TRT $\times$ G & $* *$ & $* *$ & $* *$ & $* *$ & 25 \\
D $\times$ G & $* *$ & $* *$ & $* *$ & $* *$ & 75 \\
TRT $\times$ D $\times$ G & $* *$ & $* *$ & $* *$ & $* *$ & 75 \\
\hline
\end{tabular}

$\overline{* *, \text { ss }}$ Significant at $P \leq 0.01$ or not significant at $P \leq 0.05$, respectively.

Table 2. Summary of the analysis of variance for the effects of treatment (TRT), duration of treatment (D) or genotype $(G)$ effects and their interactions $($ TRT $\times$ D) on turf quality $(T Q)$, electrolyte leakage (EL), chlorophyll content (Chl), photochemical efficiency $\left(F_{\mathrm{v}} / F_{\mathrm{m}}\right)$, and relative water content (RWC) measured at 7, 14, 21, and $28 \mathrm{~d}$ of drought treatment for 26 cultivars of hard fescue, chewings fescue, strong creeping red fescue, sheep fescue, and slender creeping red fescue.

\begin{tabular}{lcccccr}
\hline Source of variance & TQ & EL & Chl & $F_{\mathrm{v}} / F_{\mathrm{m}}$ & $\mathrm{RWC}$ & $\mathrm{df}$ \\
\hline Treatment (TRT) & $* *$ & $* *$ & $*$ & $* *$ & $* *$ & 1 \\
Duration of treatment (D) & $* *$ & $* *$ & $* *$ & $* *$ & $* *$ & 3 \\
Genotype (G) & $* *$ & $* *$ & $* *$ & $* *$ & $* *$ & 25 \\
TRT $\times$ D & $* *$ & $* *$ & $* *$ & $* *$ & $* *$ & 3 \\
TRT $\times$ G & $* *$ & $* *$ & $* *$ & $* *$ & $* *$ & 25 \\
D $\times$ G & $* *$ & $* *$ & $* *$ & $* *$ & $* *$ & 75 \\
TRT $\times$ D $\times$ G & $* *$ & $* *$ & $* *$ & $* *$ & $* *$ & 75 \\
\hline
\end{tabular}

**, * Significant at $P \leq 0.01$ or $P \leq 0.05$, respectively. drought treatment for chewings fescues and strong creeping red fescues, whereas only a transient decline was detected at $14 \mathrm{~d}$ for slender creeping red fescues, hard fescues, and sheep fescues (Fig. 6). At $28 \mathrm{~d}$ of drought treatment, the $F_{\mathrm{v}} / F_{\mathrm{m}}$ of chewings fescues declined to 0.588 0.729 , strong creeping red fescues and slender creeping red fescues declined to $0.560-0.798$ and $0.746-0.768$, respectively, whereas hard fescues and sheep fescues declined to $0.733-$ 0.823 or $0.775-0.796$, respectively.

The Chl showed a transient increase at the early stage ( 7 and $14 \mathrm{~d}$ ) of heat stress and then a slight decrease to lower level compared with respective control at $28 \mathrm{~d}$ of heat stress (Fig. 7). Under drought stress, no consistent change in $\mathrm{Chl}$ was detected (Fig. 8). However, a transient increase in Chl was detected compared with respective controls at $14 \mathrm{~d}$ drought stress and ultimately was maintained at a similar level to that of controls despite the prolonged stress.

In response to drought stress, RWC of leaf tissue began declining at $4 \mathrm{~d}$ of drought treatment in fine fescue cultivars (Fig. 9). Most cultivars of chewings fescue had RWC dropped below $50 \%$ (37\% to $50 \%)$ beginning at $21 \mathrm{~d}$ of drought stress. Most hard fescues, sheep fescues, slender creeping red fescues,

Table 3. Correlations among turf quality (TQ), electrolyte leakage (EL), photochemical efficiency $\left(F_{\mathrm{v}} / F_{\mathrm{m}}\right)$, and relative change in chlorophyll content $(\mathrm{Chl})$ at $21 \mathrm{~d}$ of heat stress for 26 cultivars of hard fescue, chewings fescue, strong creeping red fescue, sheep fescue, and slender creeping red fescue.

\begin{tabular}{lrccc}
\hline Parameters & $F_{\mathrm{v}} / F_{\mathrm{m}}$ & EL & TQ & $\begin{array}{c}\text { Relative change } \\
\text { in Chl }\end{array}$ \\
\hline$F_{\mathrm{v}} / F_{\mathrm{m}}$ & 1 & & & \\
EL & $-0.87^{* *}$ & 1 & & \\
TQ & $0.87^{* *}$ & $-0.86^{* *}$ & 1 & \\
Relative change in Chl & $0.82^{* *}$ & $-0.81^{* *}$ & $0.77^{* *}$ & 1 \\
\hline
\end{tabular}

**Significant at $P \leq 0.01$. 
and strong creeping red fescues maintained RWC above 50\%(53\% to $77 \%, 67 \%$ to $79 \%, 62 \%$ to $66 \%$, or $47 \%$ to $71 \%$, respectively) at $21 \mathrm{~d}$ of drought stress. At the end of drought treatment, the RWC of chewings fescues were $27 \%$ to $35 \%$, slender creeping red fescues and strong creeping red fescues were $45 \%$ to $49 \%$ or $37 \%$ to $66 \%$, respectively, whereas the RWC of hard fescues and sheep fescues were $49 \%$ to $77 \%$ or $51 \%$ to $63 \%$, respectively.

GENOTYPIC VARIATION UNDER HEAT AND DROUGHT STRESS. There were significant effects due to heat treatment (TRT) for TQ, EL, $F_{\mathrm{v}} / F_{\mathrm{m}}$, and due to drought treatment (TRT) for TQ, EL,
RWC, $F_{\mathrm{v}} / F_{\mathrm{m}}, \mathrm{Chl}$, indicating these parameters respond to heat stress, drought stress, or both (Tables 1 and 2). The interaction effect of TRT $\times$ D and TRT $\times$ G were significant for all parameters under both heat stress and drought stress, indicating stress response was affected by stress duration and genotypic variation.

Correlation analysis was performed using TQ and physiological data at $21 \mathrm{~d}$ heat stress and $28 \mathrm{~d}$ drought stress (Tables 3 and 4), because great stress responses were observed under these dates. Correlation analysis based on the result of 21-d heat stress showed that EL, $F_{\mathrm{v}} / F_{\mathrm{m}}$, and $\mathrm{Chl}$ were significantly correlated with TQ with respective correlation coefficients of $-0.86,0.87$, and 0.77 . This result showed that leaf Chl, EL, and $F_{\mathrm{v}} / F_{\mathrm{m}}$ are good indicators for turf performance under heat stress in fine fescues. Correlation analysis based on the result of 28-d drought stress showed that EL, RWC, and $F_{\mathrm{v}} / F_{\mathrm{m}}$ were significantly correlated with TQ with respective correlation coefficients as -0.74 , 0.94 , and 0.80 , whereas no significant correlation was detected be-

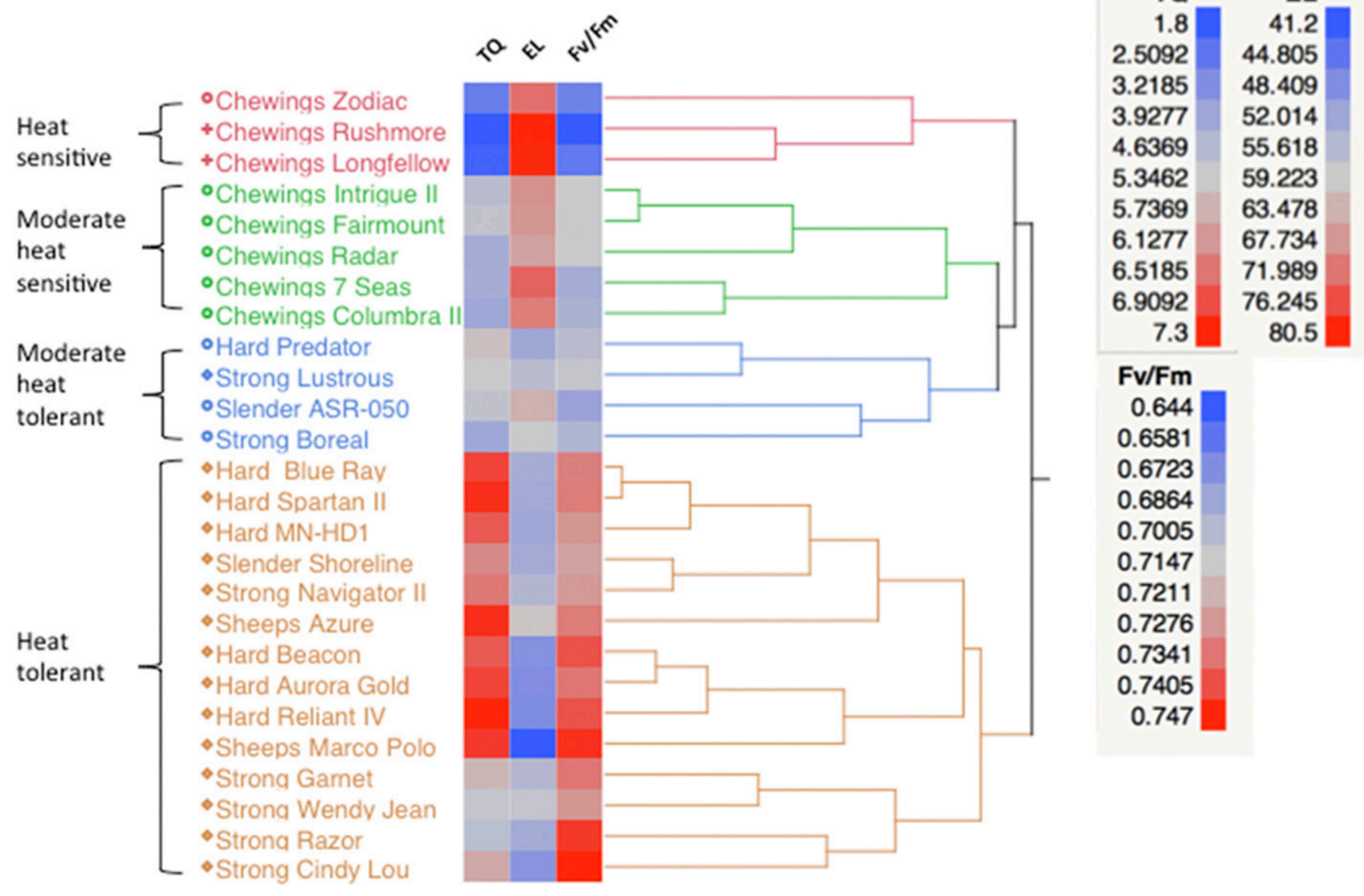

Fig. 10. Ward's cluster analysis of 26 fine fescue cultivars based on photochemical efficiency $\left(F_{\mathrm{v}} / F_{\mathrm{m}}\right)$, electrolyte leakage (EL), and turf quality (TQ) at the day 21 of heat treatment. Darker color of the value bar corresponds to higher values in terms $F_{\mathrm{v}} / F_{\mathrm{m}}$, EL, and TQ. The square brackets connect cultivars with similar $F_{\mathrm{v}} / F_{\mathrm{m}}$, $\mathrm{EL}$, and TQ. Based on the grouping by the square brackets, the 26 cultivars were categorized into four groups including "heat sensitive," "moderate heat sensitive," "moderate heat tolerant," and "heat tolerant" cultivars. 
tween Chl and TQ. This result showed that EL, RWC, and $F_{\mathrm{v}}$ $/ F_{\mathrm{m}}$ are good indicators for turf performance under drought stress in fine fescues.

The genetic variation of heat tolerance in fine fescues was determined by Ward's cluster analysis using TQ, EL, and $F_{\mathrm{v}} / F_{\mathrm{m}}$. All 26 fine fescue cultivars were classified into four groups (Fig. 10). Several cultivars with good heat tolerance were selected, including 'Blue Ray', 'Spartan II', 'MN-HD1', 'Shoreline', 'Navigator II', 'Azure', 'Beacon', 'Aurora Gold', 'Reliant IV', 'Marco Polo', 'Garnet', 'Wendy Jean', 'Razor', and 'Cindy Lou'. The genetic variation of drought tolerance in fine fescues was determined by Ward's cluster analysis using TQ, RWC, $F_{\mathrm{v}} / F_{\mathrm{m}}$, and EL (Fig. 11). Several cultivars with good drought tolerance were selected, including 'Spartan II', 'MNHD1', 'Reliant IV', 'Garnet', 'Azure', and 'Aurora Gold'.

\section{Discussion}

Under heat stress, decreased Chl content, loss of membrane stability, and declined $F_{\mathrm{v}} / F_{\mathrm{m}}$ has been reported in various coolseason grass species (Abraham et al., 2004; Larkindale and Huang, 2004; Wang et al., 2009). In this study, EL showed the most dramatic change under heat stress, suggesting cell membranes are major sites for heat damage. The increase in EL indicates loss of membrane integrity and partial dysfunction of membrane selective permeability (Bajji et al., 2002). Sustaining the function of cell membranes is critical in maintaining cellular activities under stress conditions and therefore greatly influences the stress tolerance of plants (Wahid et al., 2007). Heat-induced leaf senescence is characterized by limited photosynthetic capacity caused by declined Chl content and $F_{\mathrm{v}} / F_{\mathrm{m}}$ (Abraham et al., 2004; Cui et al., 2006; Watkins et al., 2007). In this study, significant change in $F_{\mathrm{v}} / F_{\mathrm{m}}$ and EL was observed in response to heat stress and strong correlation between TQ and these physiological parameters were detected, suggesting these traits may serve as indicators for evaluation of heat tolerance in fine fescues.

Under drought stress, decreased Chl, decreased $F_{\mathrm{v}} / F_{\mathrm{m}}$, decreased RWC, and increased EL have been reported in various cool-season grass species (Bian and Jiang, 2009; Fu and Huang, 2001; Huang and Gao, 1999). In this study, leaf RWC showed the most dramatic change and greatest variation in response to drought stress, suggesting the importance of maintaining leaf water content during prolonged drought stress. The improved maintenance of RWC under drought stress could be contributed by improved water-uptake ability at low soil water conditions (Volaire et al., 1998) and improved dehydration resistance of tissues and organs (Volaire and Lelievre, 2001). It is well documented that drought-tolerant cultivars exhibit higher leaf RWC compared with drought-sensitive cultivars under prolonged drought conditions, as demonstrated in various cool-season grass

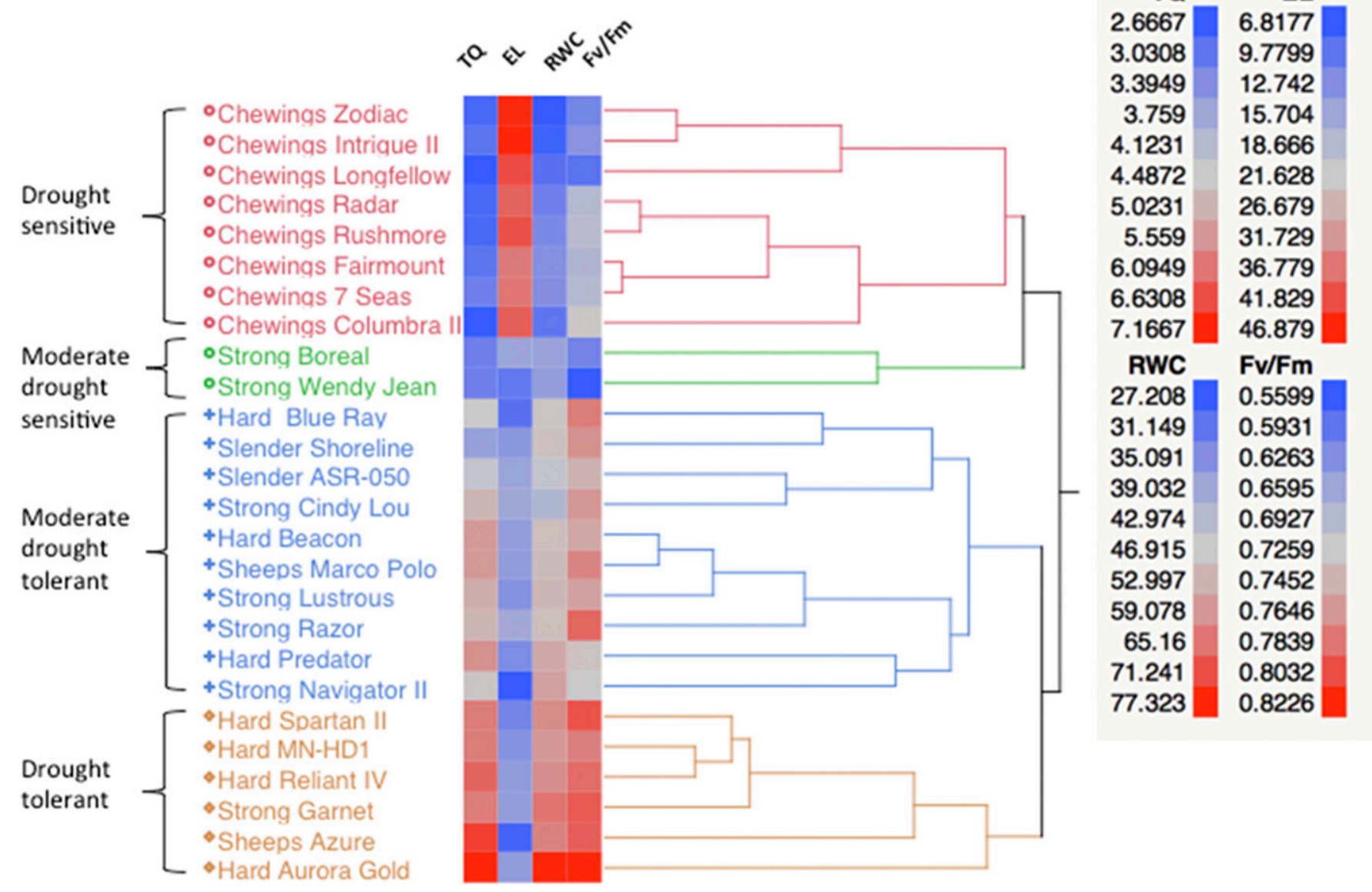

Fig. 11. Ward's cluster analysis of 26 fine fescue cultivars base on photochemical efficiency $\left(F_{\mathrm{v}} / F_{\mathrm{m}}\right)$, electrolyte leakage (EL), relative water content (RWC), and turf quality (TQ) at day 28 of drought treatment. Darker color of the value bar corresponds to higher values in terms $F_{\mathrm{v}} / F_{\mathrm{m}}$, EL, and TQ. The square brackets connect cultivars with similar $F_{\mathrm{v}} / F_{\mathrm{m}}, \mathrm{EL}$, and TQ. Based on the grouping by the square brackets, the 26 cultivars were categorized into four groups including "drought sensitive," "moderate drought sensitive," "moderate drought tolerant," and "drought tolerant" cultivars. 
species, including kentucky bluegrass (Abraham et al., 2004), tall fescue (Cross et al., 2013), and perennial ryegrass (Jiang and Fry, 1998). In addition, cell membrane stability is a critical factor to maintain efficient cellular activities and EL is a common indicator for assessing drought tolerance (Blum and Ebercon, 1981; Marcum, 1998). In this study, significant change in EL, RWC, and $F_{\mathrm{v}} / F_{\mathrm{m}}$ was observed in response to drought stress and strong correlation between TQ and these physiological parameters were detected under drought stress, suggesting these traits could serve as indicators for evaluation of drought tolerance in fine fescues.

In summary, the TQ and physiological parameters' results demonstrated that fine fescues were more sensitive to heat stress than drought stress, and there were greater genotypic variations in heat tolerance than drought tolerance within fine fescue species. Cross et al. (2013) examined whether genotypic variations in tall fescue summer turf performance is related primarily to heat tolerance or drought tolerance for 24 tall fescue selections and concluded that top-performing tall fescue cultivars during summer stress was mainly due to superior heat tolerance. Our results suggested that there was a greater potential for improving heat-tolerance than for drought tolerance in the fine fescues due to greater sensitivity to heat stress and greater genotypic variation of heat tolerance. Several cultivars with high heat tolerance were selected, as 'Blue Ray', 'Spartan II', 'MN-HD1', 'Shoreline', 'Navigator II', 'Azure', 'Beacon', 'Aurora Gold', 'Reliant IV', 'Marco Polo', 'Garnet, Wendy Jean', 'Razor', and 'Cindy Lou'; and several cultivars with high drought tolerance were selected, as 'Spartan II', 'MNHD1', 'Reliant IV', 'Garnet', 'Azure', and 'Aurora Gold'. The better heat tolerance in these cultivars would be contributed by better maintenance of photochemical efficiency and membrane stability under heat stress. In addition to photochemical efficiency and membrane stability, the better drought tolerance would also be associated with better maintenance of RWC under drought conditions. These traits would be used as indicators for heat tolerance, drought tolerance, or both in fine fescues.

\section{Literature Cited}

Abraham, E.M., B. Huang, S.A. Bonos, and W.A. Meyer. 2004. Evaluation of drought resistance for texas bluegrass, kentucky bluegrass, and their hybrids. Crop Sci. 44:1746-1753.

Arnon, D.I. 1949. Copper enzymes in isolated chloroplasts. Polyphenoloxidase in Beta vulgaris. Plant Physiol. 24:1-15.

Bajji, M., J.-M. Kinet, and S. Lutts. 2002. The use of the electrolyte leakage method for assessing cell membrane stability as a water stress tolerance test in durum wheat. Plant Growth Regulat. 36:61-70.

Barrs, H. and P. Weatherley. 1962. A re-examination of the relative turgidity technique for estimating water deficits in leaves. Austral. J. Biol. Sci. 15:413-428.

Beard, J.B. 1972. Turfgrass: Science and culture. Pearson Higher Educ., London, UK.

Bian, S. and Y. Jiang. 2009. Reactive oxygen species, antioxidant enzyme activities and gene expression patterns in leaves and roots of kentucky bluegrass in response to drought stress and recovery. Sci. Hort. 120:264-270.

Blum, A. and A. Ebercon. 1981. Cell membrane stability as a measure of drought and heat tolerance in wheat. Crop Sci. 21:43-47.

Carrow, R. and R. Duncan. 2003. Improving drought resistance and persistence in turf-type tall fescue. Crop Sci. 43:978-984.

Christians, N.E. and M. Engelke. 1994. Choosing the right grass to fit the environment, p. 99-113. In: A.R. Leslie (ed.). Handbook of integrated pest management for turf and ornamentals. CRC Press, Boca Raton, FL.
Cross, J.W., S.A. Bonos, B. Huang, and W.A. Meyer. 2013. Evaluation of heat and drought as components of summer stress on tall fescue genotypes. HortScience 48:1562-1567.

Cui, L., J. Li, Y. Fan, S. Xu, and Z. Zhang. 2006. High temperature effects on photosynthesis, PSII functionality and antioxidant activity of two Festuca arundinacea cultivars with different heat susceptibility. Bot. Stud. 47:61-69.

$\mathrm{Fu}$, J. and B. Huang. 2001. Involvement of antioxidants and lipid peroxidation in the adaptation of two cool-season grasses to localized drought stress. Environ. Expt. Bot. 45:105-114.

Hiscox, J.T. and G. Israelstam. 1979. A method for the extraction of chlorophyll from leaf tissue without maceration. Can. J. Bot. 57:1332-1334.

Huang, B., M. DaCosta, and Y. Jiang. 2014. Research advances in mechanisms of turfgrass tolerance to abiotic stresses: From physiology to molecular biology. Crit. Rev. Plant Sci. 33:141-189.

Huang, B. and H. Gao. 1999. Physiological responses of diverse tall fescue cultivars to drought stress. HortScience 34:897-901.

Jiang, H. and J. Fry. 1998. Drought responses of perennial ryegrass treated with plant growth regulators. HortScience 33:270-273.

Jiang, Y. and B. Huang. 2000. Effects of drought or heat stress alone and in combination on kentucky bluegrass. Crop Sci. 40:13581362 .

Jiang, Y. and B. Huang. 2001. Drought and heat stress injury to two cool-season turfgrasses in relation to antioxidant metabolism and lipid peroxidation. Crop Sci. 41:436-442.

Karcher, D.E., M.D. Richardson, K. Hignight, and D. Rush. 2008. Drought tolerance of tall fescue populations selected for high root/ shoot ratios and summer survival. Crop Sci. 48:771-777.

Kunkel, K., L. Stevens, S. Stevens, L. Sun, E. Janssen, D. Wuebbles, S. Hilberg, M. Timlin, L. Stoecker, and N. Westcott. 2013. Part 9. Climate of the contiguous United States. Natl. Oceanic and Atmospheric Administration Tech. Rpt. 142:46-52.

Larkindale, J. and B. Huang. 2004. Changes of lipid composition and saturation level in leaves and roots for heat-stressed and heatacclimated creeping bentgrass (Agrostis stolonifera). Environ. Expt. Bot. 51:57-67.

Liu, X. and B. Huang. 2000. Heat stress injury in relation to membrane lipid peroxidation in creeping bentgrass. Crop Sci. 40:503-510.

Marcum, K.B. 1998. Cell membrane thermostability and whole-plant heat tolerance of kentucky bluegrass. Crop Sci. 38:1214-1218.

McCann, S.E. and B. Huang. 2008. Evaluation of drought tolerance and avoidance traits for six creeping bentgrass cultivars. HortScience 43:519-524

Topp, G.C., J. Davis, and A.P. Annan. 1980. Electromagnetic determination of soil water content: Measurements in coaxial transmission lines. Water Resour. Res. 16:574-582.

Turgeon, A.J. 1996. Turfgrass management. Prentice-Hall, Englewood Cliffs, NJ.

Turgeon, A.J. 2011. Turfgrass management. Pearson Higher Educ., London, UK.

Volaire, F. and F. Lelievre. 2001. Drought survival in Dactylis glomerata and Festuca arundinacea under similar rooting conditions in tubes. Plant Soil 229:225-234.

Volaire, F., H. Thomas, and F. Lelievre. 1998. Survival and recovery of perennial forage grasses under prolonged Mediterranean drought: I. Growth, death, water relations and solute content in herbage and stubble. New Phytol. 140:439-449.

Wahid, A., S. Gelani, M. Ashraf, and M.R. Foolad. 2007. Heat tolerance in plants: An overview. Environ. Expt. Bot. 61:199-223.

Wang, J., L. Cui, Y. Wang, and J. Li. 2009. Growth, lipid peroxidation and photosynthesis in two tall fescue cultivars differing in heat tolerance. Biol. Plant. 53:237-242.

Wang, J.P. and S.S. Bughrara. 2008. Evaluation of drought tolerance for Atlas fescue, perennial ryegrass, and their progeny. Euphytica 164:113-122.

Watkins, E., B. Huang, and W.A. Meyer. 2007. Tufted hairgrass responses to heat and drought stress. J. Amer. Soc. Hort. Sci. 132:289-293. 